\title{
A Self-Critical Phenomenology of Criticism
}

\author{
JOSHUA M. HALL
}

\author{
Living in an Artworld \\ By Noël Carroll. 388 pp. \\ Louisville, Ky.: Chicago Spectrum Press, 2012. $\$ 22.50$. \\ ISBN 978-158374-220-4.
}

Noël Carroll, a central figure in analytic (Anglo-American) philosophy of art, and spouse of renowned dance scholar Sally Banes (who co-authored several of these essays), offers us something remarkable in his new book-namely, a collection of thirty years of his theoretical essays and dance reviews. Carroll wrote some of the pieces while he was a graduate student at the University of Illinois, Chicago, and there have been some dramatic changes since then in both the art world and Carroll's philosophical views. Thus, he modestly characterizes the book as "an archeological artifact" of a "somewhat confessional" variety (p. 267). Inspired by Carroll, I too will adopt an archeological stance, with a promise that the reader's patience will be repaid with something surprising at the end of the dig.

To begin with a panoramic view of the site: Living in an Artworld is divided into three sections, on dance, performance/theater, and the fine arts, respectively. I will focus primarily on the dance section (because I am writing for a dance studies readership, and my own background is in dance), but the most helpful point of entry into the book is to be found in Carroll's presentday introduction to the fine arts section. There, he relates a question posed to him by (among others) famed choreographer Yvonne Rainer: why is he tougher on critics than he is on artists, "even when," as Carroll concedes, "the artists in question may share theoretical biases with the commentators whose arguments I dissect relentlessly" (p. 266). His response to this question hinges on a separation of the domains of "imagination" and "knowledge," as a result of which, Carroll writes, "artists can produce interesting work, even if their philosophical assumptions are wrongheaded," whereas critics' theories "stand or fall on their epistemic value" (p. 266). In short, artists can be simultaneously wrong and good, but a critic who is wrong has no redeeming goodness.

However, Carroll proceeds to blur these lines between imagination and knowledge, and artists and critics. He considers the possibility that 
"avant-garde artworks can be vehicles for theorizing"; perhaps they educate audiences by "subverting their expectation" (pp. 266-67). Ultimately, he dismisses this possibility, but nonetheless acknowledges that it guided the "rhetorical strategies" that "are in evidence throughout my book, especially in my dance reviews" (p. 267). In other words, while Carroll proposes, in the present, that this boundary between art and theory is untenable, he still criticizes himself for having, in the past, questioned its existence.

One uncomfortable implication of Carroll's postulation of this boundary is that his own dance reviews in Living in an Artworld may be themselves irredeemable, qua criticism, due to a theoretical flaw (i.e., they cross the theory/art boundary). To his credit, Carroll actually draws this conclusion, and even goes so far as to admit that "to a certain extent, I became aware of the extravagances of this mode of explication" - that is, a mode of explication that assumes that artworks potentially educate by subverting expectations"by reflecting on my own practice" (p. 267). In the terminologies of the continental tradition of philosophy, Carroll's dance criticism either overcomes itself (à la Nietzsche, forerunner of existentialism) or constitutes a kind of dialectic in which criticism comes to a more sophisticated self-understanding (à la Hegel, forerunner of phenomenology).

Carroll's introduction to his dance reviews and essays contextualizes them in the 1970s and 1980s downtown New York art scene, where they first appeared in publications such as Artforum, The Soho Weekly News, The Drama Review, Dance Magazine, and The Village Voice. As Arthur Danto remarks in his foreword to Living in an Artworld, Carroll's reviews had "scarcely any circulation outside the sphere in which the readers [the performers and their audience members] were the subjects addressed, since the art was entirely for and by them" (p. 13). In those days the author espoused his views within a largely self-enclosed community, which helps to explain what one might call their theoretical homogeneity. In this milieu, Carroll writes, "I became a citizen of the avant-garde artworld," and with his friends, "learned to talk the talk by joining the conversation midstream" like "young children" (p. 18). Hearing lively debates "surrounding the work of artists like John Cage, Robert Rauschenberg, Robert Morris, and others" tempted him to join in (p. 25).

Eventually-and here is the archaeological artifact-Carroll came to see himself as engaged in "what might be called amateur phenomenology" (p. 26). But immediately the author demurs, claiming it is unclear whether he and the choreographers about whom he was writing were actually doing phenomenology. Perhaps Carroll is thinking here of Husserl's famous conception of phenomenology_namely, bracketing one's biases in order to get to the things themselves. "It seemed obvious to me," Carroll writes, "that what was important was the experience of the dance itself on its own terms"a view in which he now finds "much that is confused, oversimplified and 
naive" (p. 27). In other words, he doubts whether he ever got down to the dances themselves with his amateur phenomenological method. Given Carroll's previous insight that he tends to be unduly harsh with critics, I suggest that he might be doing the same here with his younger self. So we should not accept this piece of self-criticism too hastily.

At first merely implicitly, and then explicitly, Carroll defends his concept of "situational criticism" on the grounds that, although admittedly flawed, it nevertheless amounts to "a pre-emptive strike against the incursion of certain fashionable theoretico-critical jargons, such as poststructuralism, into dance criticism" (p. 28). Ironically, then, the most inspiring moments in Living in an Artworld are precisely those when Carroll articulates his own phenomenology. My own point of view is that dance scholars should embrace not Carroll's concept of "situational criticism" (which, as noted below, focuses exclusively on the choreographer's conscious choices), but instead what I will term "poetic criticism"-a concept that more accurately describes his best criticism in this book.

Carroll's overarching goal in the dance section of Living in an Artworld is to trace the history of art dance (which I would further specify as New York concert dance) from the 1960s to the early 1980s. This is a history helpfully telescoped in "The Return of the Repressed: The Re-emergence of Expression in Contemporary American Dance." In this piece, Carroll distinguishes "three phases of avant-garde choreography since the sixties," namely (1) the Judson Theater's "free-wheeling revolt" against modern dance; (2) a shift to a "positive" program from 1971 to 1973 (which Banes calls "analytic postmodern dance"); and (3) a "postmodernist . . . cluster of anti-minimalist tendencies" amounting to a "re-emergence of expression" (pp. 127, 128, emphasis in original). This framework helps to situate Carroll's chronologically arranged dance reviews, many of which are preceded by what he labels "theoretical" essays (the debatable implication being that dance criticism per se is not fully theoretical). The first of these essays, "Theater, Dance, and Theory: A Philosophical Narrative," originally published in 1992, refutes the idea that his model of revolt-minimalism-expression reduces to a mere vacillation from theater to movement and back to theater. On the contrary, Carroll insists, the way "dance theorists line up with respect to the relation of theater to dance depends on the conceptual constraints of the art theory that they bring to the question of the dance" (p. 36).

Note that here Carroll seems to view choreographers and dance critics (whom he includes under the umbrella of dance theorists) as passively absorbing philosophical theories, a view that underestimates dance's power to generate rather than merely imitate thought. In fact, evidence for dance's thought-generating power can be found in Carroll's own philosophy, insofar as his own thinking has obviously been shaped by his experiences in the dance world (as can be seen in the reviews reprinted in this collection). Does anyone really think that Carroll's philosophical development would 
have progressed as it has without Steve Paxton's Satisyfin' Lover or Banes's historical analyses of this dance and others?

Banes co-authored the next theoretical essay, "Cunningham, Balanchine, and Postmodern Dance," one of the newest (2006) and best in the book, which is not surprising in light of Banes's celebrated and complementary Terpsichore in Sneakers. ${ }^{1}$ So this essay is both co-authored with an actual dancer and choreographer and also derives a novel theoretical distinction from actual dance practices. * It teases apart a "modernist" tradition of avantgarde art from an "integrationist" one in the course of analyzing the collaborative relationship of John Cage and Merce Cunningham.

The next theoretical essay, "Postmodern Dance and Expression," first published in 1979 (twenty-seven years before the prior essay), argues that Yvonne Rainer, the choreographer whom Carroll locates at the epicenter of the first, reactive phase, can also be understood as expressive (i.e., placed with choreographers in the third, neo-expressive phase). Carroll must, of course, employ a broader sense of the word expression than the meaning in Expressionism, the movement. In short, this broader version reduces to "the expression of ideas," which Carroll insists not be confused with the claim that choreographers are verbally articulate (p. 52). In fact, Carroll regards choreographers as being often "more 'eloquent' about their conception of dance in terms of the discursive implications of their work than they are verbally" (pp. 55-56). In other words, the inarticulate choreographer's work metaphorically speaks by offering discursive implications, which then requires the literal speech of an eloquent critic to unpack those implications. Counterexamples abound, however, in the form of such verbally eloquent choreographers as Martha Graham, Merce Cunningham, Yvonne Rainer, and Bill T. Jones.

To turn now from Carroll's prefatory essays to his dance reviews, "Air Dancing" contrasts two choreographers who work in the air dancing tradition, Batya Zamir and Stephanie Evanitsky. Carroll chose them, he explains, in order "to clarify two opposing poles of artistic development in dancing" (p. 63). He puts this more starkly near the end of the essay: "In virtually every way, Zamir represents the opposite of [Evanitsky's] Multigravitational Group in the use of the body and aerial elements" (p. 69). For example, where Zamir is "concrete," Evanitsky's group is "abstract," which "suggests that the use of aerial elements is a justifiable artistic format which is able to sustain the type of 'dialog' characteristic of other art forms" (p. 69). In other words,

\footnotetext{
During her graduate school days at New York University, Banes studied with such choreographers as Simone Forti, Kenneth King, and Meredith Monk; performed in Forti's Planet; and choreographed her own pieces, including A Day in the Life of the Mind: Part 2 and Sophie Heightens the Contradiction (1983). For more information, see Andrea Harris's introduction to Sally Banes, Before, Between, and Beyond: Three Decades of Dance Writing (Madison: University of Wisconsin Press, 2007).
} 
since critics with diametrically opposed philosophies could conceivably argue about air dancing, it must be artistically legitimate. But if two critics could not argue about a dance from opposing philosophical perspectives, would that make the dance not artistically legitimate, according to Carroll?

On a brighter, phenomenological note, the most interesting parts of this particular review, the first in the volume, are its imaginative, poetic expressions. Carroll compares Zamir's "performative intelligence" to "the carpenter who, feeling a board cracking under his hammering, immediately, without deliberation, changes the tempo and force of his blows"-a simile that enriches imaginative grasp of Zamir's work (p. 65). He characterizes the elastic bands that Zamir uses to suspend herself as "virtually external muscles," and he remarks that one can, in her choreography, "literally see the play and alternation of her muscles" (p. 66). Note, in this last example, an oxymoron: a "literal" seeing of a metaphorical "play" of muscles (metaphorical because people, not organs, literally play). One could regard this play-of-muscles metaphor as a condensed symbol of, not only this review in particular, but also the reviews in the volume as a whole, insofar as they all implicitly lean toward a literary richness that Carroll attempts-but, fortunately, fails-to resist.

As with "Air Dancing," Carroll structures his second review, "Lucinda Childs and Laura Dean," around a dichotomous central theoretical point: one choreographer is intellectual and the other sensuous. As in the previous essay, the highlight of this one is a metaphor - a comparison of the spinning dancers in Laura Dean's 1971 Stamping Dance to the "whirling dervishes" of Sufi mysticism (p. 74). In addition to its admirable evocativeness, this metaphor supplies Carroll's most interesting interpretation of Dean's dance. The "overall plan of the dance," he writes, "suggests a metaphoric structure as the astral dervishes break away from the mass" (p. 74). Again Carroll explicitly references the concept of the "metaphoric" immediately after performing a metaphorical analysis. Tellingly, the reviewer backs away from his intellectual/sensuous dichotomy in the very next sentence: "To suggest a strict dichotomy between Dean and Childs according to a "physical-versusconceptual' opposition would be misleading" (p. 74). I suggest that the metaphorical, with its imaginative leaps, not only provides the best access to Dean's dance in the review, but also helps it to overcome reductive dichotomizing.

As one moves through the chronological series of reviews, a pattern emerges: a review's insightfulness is directly related to its poetic richness. For example, "Three Male Choreographers" is straightforwardly prosaic and, at least for me, did not generate much additional interest in the choreographers or their works. "Chair by David Gordon" is slightly more poetic. Carroll amusingly observes at the end of the essay (on the end of the dance) that the "ends" of the two dancers are stuck in their folding chairs. Like a good poem, this essay offers the reader a vivid and memorable image. And 
"Choreographic Canvases," which, as its metaphoric title suggests, is particularly poetic (including a description of the space between dancers as "being stretched like a piece of rubber"), is also particularly insightful (p. 86).

Finally, in "Options for Contemporary Dance Criticism," Carroll introduces three categories as alternatives to what he describes as the "overly impressionistic, subjective, evaluative, starstruck and gossipy" status quo of "traditional dance criticism" (p. 133). The first alternative, "descriptive criticism," is, according to Carroll, the worst of the three, humorously styled as "a vision of hell" for "the intellectual who hankers after the adventure of ideas" (p. 140). Carroll admits that he used to write reviews "in the spirit of what I took to be" this very same "descriptive dance criticism" (p. 135). The culprit here, however, is presumably phenomenology. Carroll also rejects a second alternative, "alternate cultural criticism." This refers to Marxist and psychoanalytical approaches, which Carroll sees as often being "forced on the dance material in such a way that the meaning and significance of the dance are distorted or occluded" (140). "As a result, Carroll affirms only his third alternative, "situational criticism," because "to explain [the choreographer's] action," it aims to "identify [the choreographer's] aims, the relevant choices afforded by the situation, and her appraisal of the situation" (p. 144). Situational criticism takes the choreographer's choices, relative to a given historical situation, as the heart of dance criticism.

In this paradigm, however, the artistry of the dancers is overshadowed by that of the choreographer, which Carroll himself acknowledges in his introduction to this section. To help solve this problem, I would offer a fourth type of dance criticism- "poetic criticism"-inspired by my favorite moments from Living in an Artworld, along with some of the most famous dance criticism in Western history-namely the work of poets such as Plato, Nietzsche, Paul Valéry, and Théophile Gautier. ${ }^{\dagger}$ Briefly put, poetic criticism is that which deliberately incorporates poetic writing (i.e., metaphor and other forms of figurative language) to evoke phenomena and to draw linkages between the known and the unknown.

I suspect Carroll might respond with skepticism to this fourth type of criticism, particularly since he criticizes aspects of continental philosophy and its literary tendencies at various places in the book's sections on performance and the visual arts. Problematically, however, Carroll's criticisms fail to truly engage with some important continental philosophers, as when he

The connection to phenomenology here is that, since the writings of Sartre and his fellow existentialists, Marxist and psychoanalytical theorizing have become increasingly intertwined with, or incorporated into, phenomenological methodology.

$\dagger \quad$ To clarify, Plato was, before he met Socrates, a tragic poet, and Nietzsche's Thus Spoke Zarathustra, for example, is often classified as a proto-prose poem. For an interesting account of the former issue, see Martin Buchner, The Drama of Ideas: Platonic Provocations in Theater and Philosophy (New York: Oxford University Press, 2010). 
dismisses twentieth-century Algerian-French philosopher Jacques Derrida's method of deconstruction - without reference to Derrida's many accounts of this method-as a "fashionable nihilism" (p. 285). If Carroll had gone deeper into Derrida, he might have encountered his explicit rejection of nihilism, following Nietzsche, in favor of renewed valuations of our shared world.

Fortunately, Carroll's perception of continental philosophy did not foreclose the possibility of his own important continental performances here. In conclusion, therefore, I wish to celebrate the dancingly poetic moments in Carroll's Living in Artworld, in part to challenge dance scholars to incorporate poetic moments into their own work, thus following in the footsteps of Carroll's admirably humble, graceful, and self-critical phenomenology.

\section{NOTE}

1. See Sally Banes, Terpsichore in Sneakers: Post-Modern Dance (Middletown, Conn.: Wesleyan University Press, 1987). 
Copyright of Dance Chronicle is the property of Routledge and its content may not be copied or emailed to multiple sites or posted to a listserv without the copyright holder's express

written permission. However, users may print, download, or email articles for individual use. 